\title{
Resilience and quality of life in chronically ill youth
}

\section{BACKGROUND}

The goal of this article is to present some issues related to the concept of resilience and subjective quality of life of youth. This study was concerned with subjective quality of life, and the variables important for adaptation in the face of stress associated with illness, treatment and hospitalization. The assessment of psychological variables included social skills/competences, sense of self-efficacy, perceived social support, coping strategies, depression and subjective quality of life.

\section{PARTICIPANTS AND PROCEDURE}

The study involved 154 participants (102 girls) aged 11-18, who were hospitalised with chronic illnesses. $K$-means cluster analysis allowed us to distinguish between three subgroups of youth, which were then compared in terms of the variables of interest.

\section{RESULTS}

Among the participants there are well-adapted and resilient individuals, individuals of intermediate levels of adap- tation and maladapted individuals (risk subgroup). These subgroups differ significantly in terms of psychosocial variables, coping strategies, depressive symptoms and subjective quality of life. Resilience co-occurs with adaptive coping strategies, low levels of depressive reactions and high quality of life.

\section{CONCLUSIONS}

Our results suggest the need to appreciate the role of protective factors for health and quality of life, and to facilitate the strengthening of the personal and social resources of less adapted individuals. It is important to take actions to help youths who fall into the risk group, who are vulnerable to abnormal adaptation processes and are at risk of further problems, affecting both their mental and somatic health.

\section{KEY WORDS}

chronic illness; protective factors; quality of life; youth; resilience 


\section{BACKGROUND}

Chronic illness experienced during childhood and adolescence can significantly interfere with the fulfilment of basic needs, as well as needs associated with developmental changes and challenges. For many teenagers, chronic illness negatively affects their functioning, adaptation, attitude towards the future, experienced emotions and quality of life (Bolig \& Weddle, 1988; Brown, Daly, \& Rickel, 2007; Drotar, 1998; Pilecka, 2002; Szewczyk, 1987). Nevertheless, illness and its associated difficulties often do not cause significant impairments, and, indeed, the illness-related stress stimulates the development of personality, resulting in greater emotional maturity (Bolig \& Weddle, 1988; Ogińska-Bulik, 2010a; 2013). Hence, it seems reasonable to ask why some children and adolescents react in a more adaptive manner than others to the experienced illness, and do not exhibit impairments and decreased quality of life? What factors are responsible for the fact that in some cases stress and adversity do not have negative consequences with regards to functioning and adaptation? When attempting to answer these questions, it is worth referring to the notion of resilience (Garmezy, 1991; Luthar, 1991; Rutter, 1987, 1993; Werner, 2003; Cierpiałkowska, 2007; Heszen \& Sęk, 2007; Borucka, 2011; Borucka \& Ostaszewski, 2008). The term was used in the context of interdisciplinary research on children, who, despite many negative experiences and adversities, developed normally, acquired social competences and ended up healthy. One of the first famous researchers studying this phenomenon was Emma Werner (1989), who performed a longitudinal study (starting in 1955) of children in risk groups on one of the Haitian islands. She came to the conclusion that not all children who were exposed to risks developed pathologically - a significant percentage of such children became normally functioning adults, and did not exhibit any impairments. This led to a new direction of research - the study of so-called protective factors, which act as a buffer for risk factors and are a prerequisite for normal development despite adversities and negative experiences. The notion of resilience is therefore associated with concepts such as risk factors, protective factors and vulnerability. Studies on resilience grounded in psychopathology were concentrated around identifying risk factors and protective factors, and they involved a continuum - at one end of which there was vulnerability, and at the other end was resilience (Rutter, 1985). Vulnerability is a predisposition or tendency for developing impairments in the face of negative experiences, and it is associated with certain risk factors such as inherited or congenital weaknesses, difficult temperament, and low intelligence. Such factors may be directly related to an individual (congen- ital weaknesses), their family (e.g. psychopathology of parents, poverty), or their environment (e.g. surrounded by crime). Protective factors are variables that explain resilience in the face of risk factors. These decrease the occurrence of negative effects of stress, fostering adaptation despite negative experiences. Protective factors reduce or alleviate the negative impact of risk factors, and modify their harmful effects, though they can also act independently of the presence of risk factors (Stewart, Reid, \& Mangham, 1997; cf. Luthar, Sawyer, \& Brown, 2006). They may be related to an individual (e.g. easy temperament, self-esteem, ability to solve problems), family (e.g. family cohesion and warmth), as well as a broader context that acts as a support system (e.g. good environment or school). The interaction between risk factors and protective factors can be conceptualised within three models: 1) the compensatory model where protective factors compensate for the influence of risk factors; 2) the protection-vulnerability model - where there is an interaction between risk factors and protective factors; and 3) the challenge model - where moderate levels of stress may serve to immunise oneself to subsequent more difficult events (Garmezy, Masten, \& Tellegen, 1984; cf. Borucka, \& Ostaszewski, 2012). Developmental studies investigating the resilience phenomenon focus on the following questions: Which variables explain normal development and/or recovery of children who are exposed to harmful, negative events? What are the natural factors and processes that protect development? What are the most effective strategies for supporting the development of children and adolescents in risk groups? (Masten \& Gewirtz, 2006).

Despite the fact that studies on resilience have been around for a long time, it is fair to say that there has been a renaissance in the last few decades. Different researchers define this phenomenon in slightly differing ways. One of the pioneers in the study of this phenomenon, Michael Rutter, defines resilience as successful adaptation despite chronic stress and adversities - "the phenomenon of resilience under stress" (Rutter, 1980, pp. 180-181). According to many authors, this construct includes two important elements: the occurrence of a serious threat to adaptation and development, and simultaneous achievement of positive adaptation and positive outcomes (Masten, 2001; Luthar, 2003; Rutter, 1990). The developmental perspective takes into account the level of the child's development and functioning, and the relationship between risk factors and protective factors as well as the child's adaptation. According to Heszen and Sęk (2007) resilience is a set of skills for efficiently dealing with severe stress, and relies on flexible (adaptable) and creative coping with adversities; the main role here is played by the ability to "bounce back' from negative experiences and the ability to incite positive emotions. Resilience may be described
Resilience and quality of life in youth 
as a multi-factor process of adaptation, where protective factors compensate for or reduce the influence of risk (Ostaszewski, 2005). In summary, resilience may be defined in terms of an individual's ability, as a personality feature, or as a process, through which one goes, and as a result or final effect in form of successful adaptation despite challenges or risky circumstances (Masten, Best, \& Garmezy, 1990). As a property of one's personality, resilience refers to the ability of an individual to healthily accustomise oneself, positively function and adapt to changes, stressful events or circumstances, as well as everyday life situations (Catalano, Berglund, Ryan, Lonczak, \& Hawkins, 2004). Resilience as a process is also an ability to reintegrate and return to normal functioning after experiencing acute stress, thanks to protective factors (Richardson, 2002). Resilience as an effect means positive and favourable outcomes resulting from successfully coping with stressful events - positive adaptation despite adversities (Masten et al., 1990). The phenomenon of resilience described using such characteristics is multi-dimensional and is a key variable for predicting positive outcomes in the face of adversities. According to Lee, Cheung and Kwong (2012) an operative definition should include all key characteristics and components, skills or properties of an individual, the process and the effects. Therefore this construct may be understood as a process of successful mobilisation of internal and external resources in the process of adaptation or coping with stress or trauma. The development of resilience by youth means shaping an ability, flexibility and coping strategy in situations of developmental changes, and life-related stresses in order to 'bounce back' from difficult experiences and achieve positive development and adaptation (Lee et al., 2012). Despite the fact that there is no formal definition of resilience, there are examples of useful research models, e.g. the Adolescent Resilience Model, based on results of a study on youth affected by cancer (Haase, Heiney, Ruccione, \& Stutzer, 1999). This model encompasses the following elements: individual protective factors (e.g. courageous coping, hope), family protective factors (e.g. atmosphere, support and resources), and social protective factors (e.g. social integration). Another example of a model is the Youth Resilience Model, in which resilience refers to an interaction between risk factors (vulnerability) and protective factors (protection). Interventions aimed at improving health guided by this framework have been shown to strengthen resilience, which leads to a reduction in undertaking risk behaviours (Rew \& Horner, 2003).

A lot of research has been conducted in order to identify factors which decrease the risk of unfavourable effects that negative events, stress and adversities may have on an individual. Such factors or resources may exist at the level of an individual, family, social environment or wider society (Rew,
2005). Researchers list the following temperamental features as protective factors: openness, ability to incite positive reactions, social competences and skills (such as empathy and caring for others), academic skills, sense of identity, internal locus of control, sense of self-efficacy, optimism, persistence and hope, sense of coherence, and personal beliefs. There are two main approaches characteristic for studying resilience: 1) the variable-focused approach and 2) the person-focused approach. The first one aims to investigate the relationships between the features of an individual, their environment and experiences, in order to identify variables which can explain good adaptation in a situation of high risk or adversities. The second one attempts to identify resilient individuals and to establish the differences between them and those who do not cope well with adversities (Masten \& Reed, 2005).

It is crucial to assess the quality of life of patients in an integrated process of treatment of the chronically ill. Apart from the medical assessment of the parameters of an illness, its effects and the outcomes of treatment, it is important to take into account the subjective evaluation of one's own health and limitations associated with an illness. The most popular definition of quality of life is the one suggested by the World Health Organization (WHO). According to the WHO, quality of life is "an individual's perception of their position in life in the context of the culture and value systems in which they live, and in relation to their goals, expectations, and concerns" (The WHOQOL Group, 1995, p. 1405). In other words, it is a multi-dimensional construct, which encapsulates the physical health of an individual, their mental state, level of independence, social relations, personal beliefs and attitude towards the significant properties of the environment. The WHO idea of quality of life is the basis of specific models and measurement tools, in particular, ones regarding children and adolescents. An example of a model that was based on the WHO definition of quality of life, as well as data gathered by interviewing 11-18-year-old youths and their caretakers, is the Youth Quality of Life model (Patrick, Edwards, \& Topolski, 2002). This theoretical model of a youth's quality of life encapsulates four areas: sense of self (created by one's own feelings towards him/herself), social relationships, environment (together with the opportunities and barriers it brings), and general quality of life. Perception of one's own position in life by youth is significant in this approach, as is an assessment of one's own quality of life in the areas which are important for this period of life (due to the associated developmental specifics and needs).

It is possible to identify some similarities and some differences between resilience and quality of life. The similarities are that both variables are of a multi-dimensional character, they are latent con- 
structs - they cannot be measured directly - and, in the case of children and adolescents, they are internally diversified due to the distinctness of assessment criteria, whereas measurement methods need to involve weighting the components according to their importance or ascribed meaning. On the other hand, the differences include the fact that a great number of quality of life studies are concerned with ill, hospitalised children, while research on resilience is often closely associated with developmental psychopathology. Researchers who study quality of life emphasize how it can be challenged during illness, while those who study resilience try to identify protective factors and a wider range of risk factors. It is possible to speak about the difference in terms of the stability of each concept. In the case of resilience, we are dealing with high levels of prognostic accuracy and relative stability in the lifetime of an individual. Due to a rather small number of studies concerned with the stability of perceived quality of life, there are no clear conclusions about it. Factors affecting quality of life change with time and across developmental periods, but if we consider the subjective assessment of quality of life to be a part of the process of cognitive assessment, the subjective quality of life of a child may be relatively stable (Lawford \& Eiser, 2001).

\section{GOAL OF THE CURRENT STUDY}

The current research project assumes an understanding of resilience as the ability of an individual to adapt and positively function despite adversities. However, this variable is not measured directly. Internal and external resources were chosen as indicators of this definition of resilience. These include high social skills, sense of self-efficacy and sense of social support, which can all be a representation of the strengths of an individual and their resilience. This choice of assessment of resilience levels was motivated by the position of some authors who believe that resilience can be measured by assessing the resources of an individual, their family and their wider environment (Olsson, Bond, Burns, Vella-Brodick, \& Sawyer, 2013). The literature indicates various correlates or definitional attributes of resilience. Features correlated with resilience include sense of self-efficacy (Rutter, 1985), social competences such as empathy, ability to cooperate, self-control, assertiveness (Alriksson-Schmidt, Wallander, \& Biasini, 2006), and social support (Luthar \& Zigler, 1991; Gomez, Vincent, \& Toussaint, 2013).

In this paper, an illness serves as a risk situation, as it is associated with a threat to life, functioning and fulfilment of typical developmental tasks of youths. The selected indicators of positive adaptation are high subjective quality of life, use of adaptive coping strategies and a lack of symptoms of depression.
Assuming that the studied youth, despite common features such as chronic illness and hospitalisation, comprise a heterogeneous group in terms of psychosocial variables, we attempted to identify subgroups of individuals sharing similarities in terms of social competences/skills, sense of self-efficacy and perceived social support (indices of resilience). The results of measurement of the above variables were used as criteria for the division into subgroups. Three subgroups of subjects were identified using $k$-means cluster analysis.

The goal of this study was to comparatively characterise the identified subgroups of youth in terms of their levels of resilience; therefore this study adopts the person-focused approach. We were concerned with the following questions:

- What are the levels of social skills and perceived support, as well as sense of self-efficacy, among chronically ill youth?

- Are different coping strategies used by youths from different subgroups?

- What are the levels of subjective quality of life among the subgroups?

- What are the levels of depressive reactions among the compared subgroups of youths?

Moreover, we aimed at a comparative analysis of the resilience level subgroups in terms of variables important for positive adaptation. Assuming that it is possible to identify a subgroup characterised by high resilience using cluster analysis, we postulated that:

H. 1. There are differences in positive adaptations, which are in line with the resilience levels, whose indicators are high social skills, sense of self-efficacy and sense of social support.

H. 1.1. Resilient youth use adaptive coping strategies significantly more often in comparison to the remaining subgroups.

H. 1.2. Resilient individuals are characterised by significantly higher levels of subjective quality of life when compared with other subgroups.

H. 1.3. Resilient youth are characterised by low intensity of depressive symptoms compared with the remaining subgroups.

Subjective quality of life, coping strategies and depressive symptoms have a dependent variable status, though in the assumed research models they do not serve as explained variables. Analyses are concerned with comparing the subgroups both in terms of variables serving as resilience criteria and variables associated with adaptation.

\section{PARTICIPANTS AND PROCEDURE}

\section{PARTICIPANTS}

A study on chronically ill youth was conducted to find answers to the aforementioned questions and
Resilience and quality of life in youth 
to verify the above hypotheses. The study involved teenagers aged 11-18 $(N=154,102$ girls $)$, hospitalised by various conditions of a chronic character. The illnesses included endocrine disorders (diabetes, obesity, idiopathic short stature, thyroid problems) ( $n=83,54 \%$ of all participants), and other chronic conditions (headaches, anorexia, neurological disorders, gastric disorders and epilepsy) ( $n=71,46 \%$ of all participants). The choice of a group that was heterogeneous in terms of illness types is in line with the so-called non-categorical approach that places emphasis on the common difficulties faced by the patients in the study, namely, the chronic character of the illness, the fact that it requires treatment and medical control and often has a lasting impact (Nowakowska, 1983; cf. Brown et al., 2007). In the non-specific approach the experiencing of a chronic illness is of central interest, regardless of its type, symptoms or treatment (Brown et al., 2007; Wallander \& Varni, 1998). Therefore if we think of an illness as a difficult situation one has to deal with, variables that are resources for successful coping (such as competences, sense of self-efficacy, coping strategies, and experienced social support) become of central importance.

\section{RESEARCH MEASURES}

The following methods were used in the current study: Social Skills Rating System (SSRS), Self-Efficacy Questionnaire for Children (SEQ-C), Multidimensional Scale of Perceived Social Support (MSPSS), Schoolagers' Coping Strategies Inventory (SCSI), Children's Depression Inventory (CDI) and Youth Quality of Life Instrument (YQOL), all in their Polish adaptations.

The Social Skills Rating System (SSRS), by Gresham and Elliot (1990), was used (Polish adaptation by Oleś, 2010). It assesses the social skills and competences of school-aged children and adolescents. Social competences form adaptive behaviours and social skills. The scale measures behaviours that are important from the point of view of psychosocial functioning, which foster positive adaptation and, ultimately, lead to favourable, important social effects, such as acceptance and popularity among peers, recognition from significant others, and academic achievements. The Polish version of the method consists of four subscales: I. Cooperation, II. Assertion, III. Empathy and IV. Self-control. The assessments are made on a 3-point scale, measuring frequency (frequently, sometimes, never). The higher the score, the higher the level of social skills. The psychometric properties of this method are satisfactory, and they indicate its high reliability and validity (Oleś, 2010).

As in the original, the Polish version of the Self-Efficacy Questionnaire for Children (SEQ-C, Muris, 2002; Polish: Skala Poczucia Wtasnej Skuteczności) measures the sense of self-efficacy in three aspects: academic, social and emotional. Sense of self-efficacy refers to seeing oneself as capable of carrying out one's intentions (Bandura, 1999). It is a strong belief in one's own competences that is formed based on varying sources of information about one's talents and skills. The Polish version of the questionnaire consists of 21 questions forming three subscales (academic, social and emotional dimensions) and a 5-point severity rating scale (not at all - very well). Due to its psychometric properties (the reliability of the scale is very high - internal consistency index, Cronbach's $\alpha=.92$ ), economy, and informativity it is a valuable tool for measuring the sense of self-efficacy of children and adolescents (Oleś, 2010).

The Multidimensional Scale of Perceived Social Support (MSPSS; Zimet, Dahlem, Zimet, \& Farley, 1988) and its Polish version, used in this study (Wielowymiarowa Skala Spostrzeganego Wsparcia Spolecznego), serve for measuring subjectively assessed social support in children, adolescents and adults. In the context of the scale, social support refers to some resources of an individual, which stem from the belonging to some social group and having one's needs fulfilled in difficult situations by significant others or a reference group. The scale can measure social support received from three sources: one's family, friends, and other significant others. It consists of 12 items and a 5-point answering scale. Its psychometric properties are satisfactory (Canty-Mitchell, \& Zimet, 2000; Oleś, 2010).

The Schoolagers' Coping Strategies Inventory (SCSI) by Ryan-Wenger (1990) and its Polish adaptation (Inwentarz Sposobów Radzenia sobie przez Uczniów) serve for assessment of coping strategies of schoolaged children. Ways or strategies of coping refer to a set of reactions of both a cognitive and behavioural kind. Ryan-Wenger (1992) identified 15 ways to react, and the inventory includes 28 detailed ways of acting in difficult situations. Their use is assessed on a 3-point scale with regards to both frequency and effectiveness. In order to group the methods of coping, factor analysis was conducted, and it revealed a 6-factor structure of the inventory: I. Aggressive and destructive behaviours, II. Substitute activities, III. Avoidance and escape, IV. Soothing or releasing emotions, V. Conscious coping with problem and VI. Controlling one's emotions and behaviours (Oleś, 2010). Both the original and the Polish version of this tool are characterised by satisfactory reliability and validity (Ryan-Wenger, 1990; Oleś, 2010).

The Children's Depression Inventory by M. Kovacs $(1980 / 81)$ is the most commonly used tool for the assessment of depressive symptoms among children and adolescents (Polish version used here: Inwentarz Depresji Dziecięcej). It is composed of 27 test items, which are concerned with cognitive, affective and behavioural symptoms of depression. Each item consists of three statements dealing with how the 
subject felt during the previous two weeks. The test has a five-factor structure: I. Negative mood, II. Interpersonal problems, III. Ineffectiveness, IV. Anhedonia, V. Negative self-esteem. The Polish version of the inventory has satisfactory psychometric properties and it is mainly used in research and screening (Oleś, 1995).

Skala fakości Życia dla Młodzieży (SJŻ-M) is the Polish adaptation of the Youth Quality of Life Instrument (YQOL) by Patrick et al. (2002) used to measure quality of life in youth aged 11-18. It is an operationalization of the quality of life model composed of four domains: I. Sense of self, II. Social Relationships, III. Environment, and IV. General quality of life. This method allows for assessment of quality of life both in a global sense and within the four domains, as does the model. It is composed of 41 test items referring to a 'perception of one's own position in life', which participants assess in terms of intensity on a $0-10$ scale. The psychometric properties of the method are satisfactory (Topolski, Edwards, \& Patrick, 2002; Oleś, 2010).

\section{STUDY PROCEDURES}

The study took place in the Endocrine and Neurology Ward of the Children's Clinical Hospital in Lublin, Poland. The participants were youths who, at the time of the study, were hospitalised with chronic illnesses. Apart from the questionnaire-type methods, which were completed in groups of several subjects at a time, a one-on-one conversation was held with each of the participants about their illness and its associated problems. The conversation also included questions about quality of life and its determinants. The answers to these questions, however, will not be used in this publication.

\section{RESULTS}

The first of these analyses was concerned with characterising the resilience level subgroups of subjects using variables selected as criteria of resilience. The obtained clusters are presented in Figure 1.

Of the three identified subgroups, one lay at each extreme, while the third, and largest, group lay in between.

Subgroup 1. Adapted (resilient) - subjects who possess personal and social resources, as evidenced by high scores for social skills, sense of self-efficacy and perceived social support; $n=54(F=37, M=17)$, that is $33 \%$ of all participants.

Subgroup 2. Risk group - subjects whose scores indicated lower levels of social skills, low sense of self-efficacy, and low perceived social support; $n=43$ ( $F=25, M=18)$, that is $27 \%$ of all participants.
Subgroup 3. Intermediate - subjects who scored low on social skills and average on self-efficacy and perceived social support, which indicates moderate levels of personal and social resources; $n=65(F=43$, $M=22$ ), $40 \%$ of all participants. It is a group of moderate level of adaptation.

With these identified subgroups, the first step of the analysis was to characterise them in terms of the investigated variables that served as criteria of resilience (social skills, sense of self-efficacy, perceived social support). Then, the subgroups were compared in terms of adaptation and positive adaptation indices - coping strategies, subjective quality of life, and the occurrence of depressive reactions.

The above results suggest that, among groups of ill, hospitalised youths, it is possible to identify individuals whose levels of social competences and skills, sense of self-efficacy and perceived social support are low. That these features of psychosocial functioning are exhibited in a difficult, stressful situation suggests that this is a special risk group - characterised by high risk of occurrence of maladaptive reactions, lower mental and emotional functioning, possible occurrence of disorders such as anxiety-depressive reactions and with the prospect of bigger problems in the future. It could be argued that the division into subgroups was conducted in such a way that it should not come as a surprise that such individuals were distinguished. There are also individuals who are characterised by significant levels of personal resources and social skills, sense of self-efficacy or perceived social support, which are associated with positive adaptation to a difficult situation. The intermediate subgroup is characterised by a moderate level of adaptation.

The results of the analysis of levels of social skills and competences of the three subgroups of chronically ill youth, measured using the Polish adaptation of Social Skills Rating System (SSRS), are presented in Table 1 and illustrated in Figure 2.

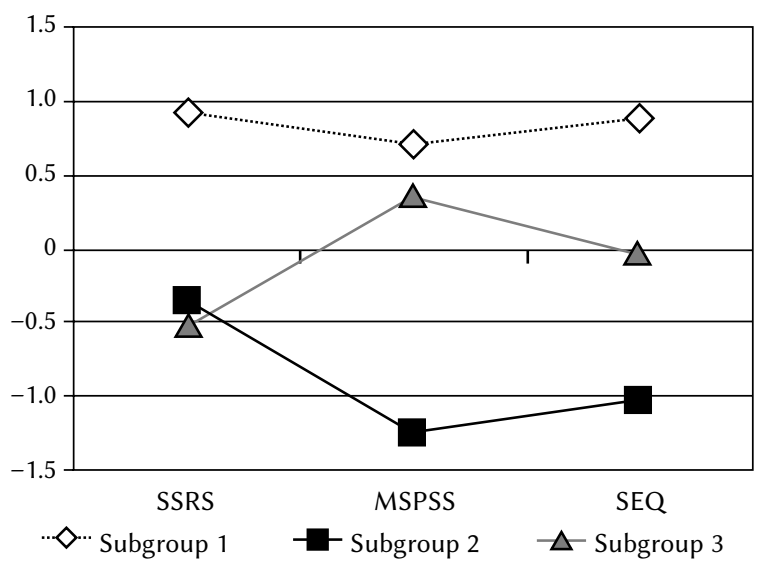

Figure 1. Subgroups of youths identified using $k$-means cluster analysis based on criterion variables - results for the SSRS, MSPSS and SEQ questionnaires.
Resilience and quality of life in youth 
Table 1

Social skills/competences - results (M and SD) on the SSRS scale for the 3 subgroups of youths; results of ANOVA

\begin{tabular}{|c|c|c|c|c|c|c|c|c|c|}
\hline & \multirow[t]{2}{*}{ Social skills } & \multicolumn{2}{|c|}{ Subgroup $1(n=54)$} & \multicolumn{2}{|c|}{ Subgroup $2(n=43)$} & \multicolumn{2}{|c|}{ Subgroup $3(n=65)$} & \multicolumn{2}{|c|}{$\begin{array}{l}\text { Significance of } \\
\text { differences }\end{array}$} \\
\hline & & $M$ & $S D$ & $M$ & $S D$ & $M$ & $S D$ & $F(2,159)$ & $p$ \\
\hline & 1. Cooperation & 32.91 & 2.76 & 28.28 & 4.45 & 27.51 & 3.09 & $40.84^{\mathrm{a}, \mathrm{b}}$ & $<.001$ \\
\hline & 2. Assertion & 32.74 & 2.73 & 28.33 & 4.49 & 28.22 & 3.73 & $26.99^{a, b}$ & $<.001$ \\
\hline & 3. Empathy & 33.87 & 1.92 & 28.84 & 4.33 & 28.68 & 3.24 & $45.56^{\mathrm{a}, \mathrm{b}}$ & $<.001$ \\
\hline \multirow[t]{2}{*}{ Maria Oleś } & 4. Self-control & 30.65 & 2.97 & 26.91 & 4.60 & 25.65 & 3.14 & $30.85^{\mathrm{a}, \mathrm{b}}$ & $<.001$ \\
\hline & SSRS-Total & 130.17 & 8.14 & 112.35 & 15.45 & 110.05 & 9.45 & $55.40^{\mathrm{a}, \mathrm{b}}$ & $<.001$ \\
\hline
\end{tabular}

Note. Differences: a - between 1 and 2, $p<.001 ; \mathrm{b}$ - between 1 and $3, p<.001$.

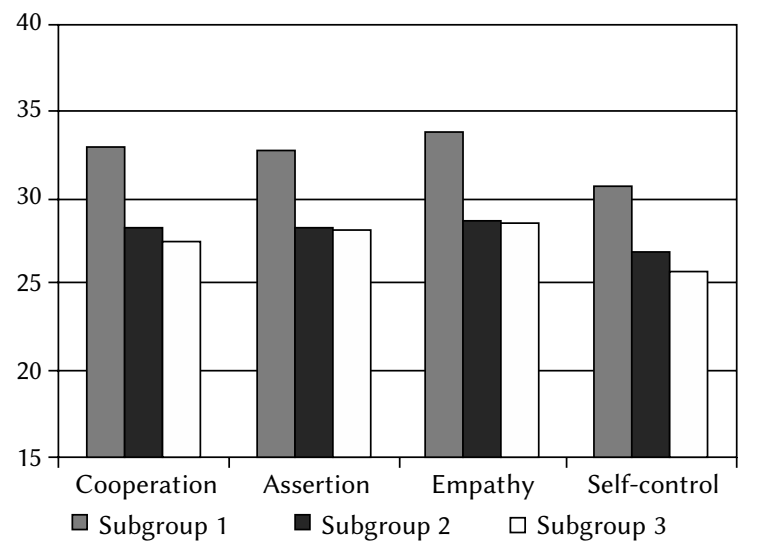

Figure 2. Social skill levels in the three subgroups of participants.

Comparative analysis suggests that the levels of social competences, both in terms of the general score and the specified social skills, differ significantly between the identified subgroups of subjects. Subjects from Subgroup 1 are characterised by the highest levels of competences manifested in the overall score (SSRS-Total). There are significant differences between the resilient subgroup (1), the risk subgroup (2) and the intermediate subgroup (3). Differences between subgroups are similar when looking at selected skills such as the ability to cooperate, assertion, empathy and self-control.
In the resilient subgroup (Subgroup 1) there are the highest levels of empathy, ability to cooperate and assertion. In the risk group, differences between the skills in question are small; self-control is the lowest, followed by ability to cooperate, assertion and empathy.

Sense of self-efficacy was assessed using the Polish adaptation of the SEQ-C questionnaire. The results of comparative analyses between the identified subgroups of youths are presented in Table 2.

Both the general score and the scores in three domains were the highest in the resilient subgroup. Significant differences in social relations, school achievements and emotions were revealed between the resilient, risk and intermediate subgroups. Subjects from the risk subgroup had a significantly lower sense of self efficacy in all domains, in comparison to both the resilient and the intermediate subgroup. Differences between subgroups are presented in Figure 3.

In the resilient subgroup, the highest levels of sense of self-efficacy were exhibited in the domains of school and interpersonal relations. In the risk subgroup the lowest sense of self-efficacy was in the emotional domain.

The levels of perceived support of the participants was measured using MSPSS, and the results are presented in Table 3 and Figure 4.

Table 2

Sense of self-efficacy - results (M and SD) for the SEQ-C questionnaire for the 3 subgroups of youth; results of ANOVA

\begin{tabular}{|c|c|c|c|c|c|c|c|c|}
\hline \multirow{2}{*}{$\begin{array}{c}\text { Sense of } \\
\text { self-efficacy } \\
\text { domains }\end{array}$} & \multicolumn{2}{|c|}{ Subgroup $1(n=54)$} & \multicolumn{2}{|c|}{ Subgroup $2(n=43)$} & \multicolumn{2}{|c|}{ Subgroup $3(n=65)$} & \multicolumn{2}{|c|}{$\begin{array}{c}\text { Significance of } \\
\text { differences }\end{array}$} \\
\hline & $M$ & $S D$ & $M$ & $S D$ & $M$ & $S D$ & $F(2,152)$ & $p$ \\
\hline 1. Social & 28.43 & 3.18 & 19.93 & 3.60 & 25.12 & 4.23 & $61.98^{\mathrm{a}, \mathrm{b}, \mathrm{c}}$ & $<.001$ \\
\hline 2. School-related & 28.70 & 4.35 & 20.09 & 4.28 & 24.79 & 3.98 & $50.66^{\mathrm{a}, \mathrm{b}, \mathrm{c}}$ & $<.001$ \\
\hline 3. Emotional & 26.48 & 4.31 & 19.65 & 3.76 & 22.22 & 3.77 & $37.59^{\mathrm{a}, \mathrm{b}, \mathrm{d}}$ & $<.001$ \\
\hline SEQ-Total & 83.61 & 9.70 & 59.67 & 9.48 & 72.12 & 8.24 & $83.18^{\mathrm{a}, \mathrm{b}, \mathrm{c}}$ & $<.001$ \\
\hline
\end{tabular}

Note. Differences between subgroups: $\mathrm{a}-1$ and $2, p<.001 ; b-1$ and $3, p<.001 ; \mathrm{c}-2$ and $3, p<.001, \mathrm{~d}-2$ and $3, p<.01$. 


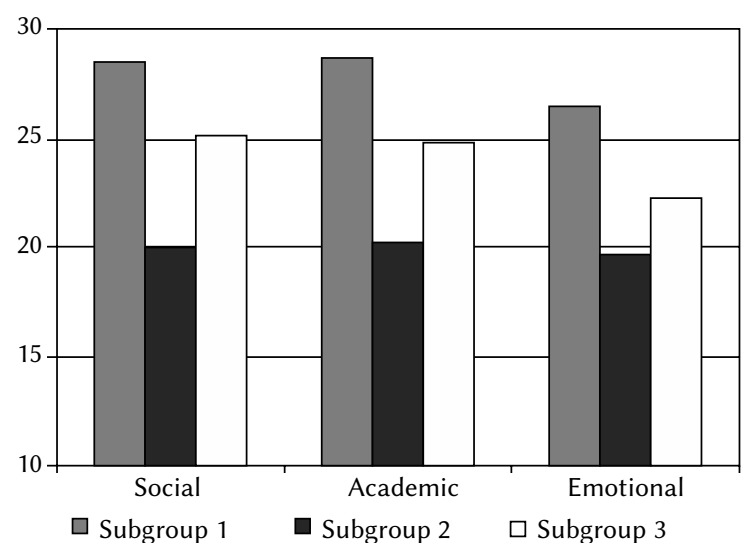

Figure 3. Sense of self-efficacy in the subgroups of youth in three domains of functioning.

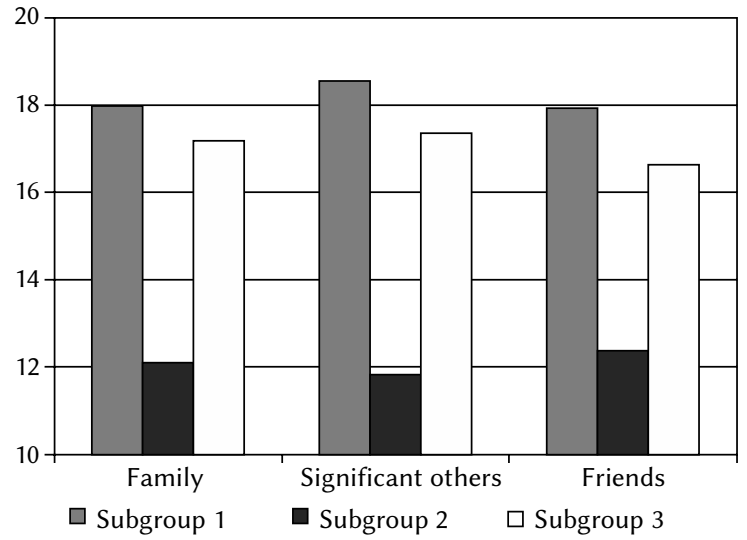

Figure 4. Levels of perceived social support in the three subgroups of participants.

Table 3

Levels of perceived social support - results (M and SD) on the MSPSS scale for the 3 subgroups of youths; results of ANOVA

\begin{tabular}{lcccccccc}
\hline \multicolumn{1}{c}{ Social support } & \multicolumn{1}{c}{ Subgroup 1 $(n=54)$} & Subgroup 2 $(n=43)$ & Subgroup 3 $(n=65)$ & $\begin{array}{c}\text { Significance of } \\
\text { differences }\end{array}$ \\
\cline { 2 - 9 } & $M$ & $S D$ & $M$ & $S D$ & $M$ & $S D$ & $F(2,152)$ & $p$ \\
\hline 1. Family & 17.98 & 2.19 & 12.09 & 2.82 & 17.17 & 2.34 & $80.86^{\mathrm{a}, \mathrm{b}}<.001$ \\
2. Significant others & 18.57 & 1.93 & 11.79 & 3.14 & 17.34 & 2.35 & $99.99^{\mathrm{a}, \mathrm{b}, \mathrm{c}}<.001$ \\
3. Friends & 17.93 & 2.19 & 12.35 & 2.31 & 16.68 & 2.73 & $66.92^{\mathrm{a}, \mathrm{b}, \mathrm{c}}<.001$ \\
MSPSS-Total & 54.48 & 4.97 & 36.23 & 5.87 & 51.18 & 5.44 & $151.55^{\mathrm{a}, \mathrm{b}, \mathrm{c}}<.001$ \\
\hline
\end{tabular}

Note. Differences between subgroups: $\mathrm{a}-1$ and $2, p<.001 ; \mathrm{b}-2$ and $3, p<.001 ; \mathrm{c}-1$ and 3, $p<.05$.

The highest levels of perceived support were observed among participants from the resilient subgroup. Youths from the risk subgroup had significantly lower levels of perceived support in comparison with both the resilient and intermediate subgroups. In terms of sources of support, the resilient subgroup reported significantly higher levels of support coming from family, friends and significant others compared to the other two subgroups.

Significant differences in these three sources of social support could be seen also between the risk and the intermediate subgroups. In comparison with the other subgroups, individuals from the risk subgroup were characterised by significantly lower levels of perceived support from family, significant others and peers.

Subsequent comparative analyses of the three identified subgroups regarded their assessment in terms of positive adaptation. The SCSI by RyanWenger was the basis for assessing the subjects across 6 coping strategies identified using factor analysis (Oleś, 2010). Results for the three compared subgroups are presented in Table 4 and Figure 5.

No significant differences between the subgroups were observed in four out of six coping strategies: S.2. Substitute activities, S.3. Avoidance and escape,
S.4. Soothing or releasing emotions, and S.6. Controlling one's emotions and behaviours. We found that in each of the subgroups, participants use these strategies equally often. Differences were observed with regards to the non-adaptive strategy S.1. Aggressive and destructive behaviours - this strategy was used significantly more often in the risk subgroup than in the resilient and intermediate subgroups. The adaptive strategy - conscious addressing of the problem - was used significantly more often by the resilient subgroup than by the two other subgroups. In the resilient and intermediate subgroup, the most popular coping strategies were conscious addressing of the problem and substitute activities, while among the youths in the risk subgroup substitute activities and avoidance-escape were used most frequently.

The above figure illustrates the frequency of each of the coping strategies among the subgroups. The youths in the study distract themselves most often by doing such things as watching television, eating, doing homework, and playing games. They cope by getting away from the problem and immersing themselves in unrelated activities; but they also try to find solutions to difficult situations by searching for support or information. The least frequently used strategy was the non-adaptive strategy of aggressive and
Resilience and quality of life in youth 
Table 4

Comparisons of coping strategies - results (M and SD) for the SCSI inventory for the 3 subgroups of youths; results of ANOVA

\begin{tabular}{lcccccccc}
\hline \multirow{2}{*}{$\begin{array}{c}\text { Coping } \\
\text { strategies }\end{array}$} & \multicolumn{2}{c}{ Subgroup $1(n=54)$} & Subgroup $2(n=43)$ & Subgroup $3(n=65)$ & \multicolumn{2}{c}{$\begin{array}{c}\text { Significance of } \\
\text { differences }\end{array}$} \\
\cline { 2 - 10 } & $M$ & $S D$ & $M$ & $S D$ & $M$ & $S D$ & $F(2,152)$ & $p$ \\
\hline S.1. & 0.38 & 0.42 & 0.81 & 0.65 & 0.67 & 0.56 & $7.78^{\mathrm{a}, \mathrm{b}}$ & $<.001$ \\
S.2. & 1.76 & 0.47 & 1.69 & 0.52 & 1.68 & 0.47 & 0.45 & n.s. \\
S.3. & 1.57 & 0.65 & 1.36 & 0.56 & 1.48 & 0.49 & 1.51 & n.s. \\
S.4. & 0.96 & 0.62 & 1.04 & 0.56 & 0.97 & 0.56 & 0.25 & n.s. \\
S.5. & 1.88 & 0.62 & 1.43 & 0.55 & 1.65 & 0.61 & $6.67^{\mathrm{a}}$ & $<.01$ \\
S.6. & 1.28 & 0.58 & 1.29 & 0.45 & 1.40 & 0.41 & 1.12 & n.s. \\
\hline
\end{tabular}

Note. Differences between subgroups: $\mathrm{a}-1$ and $2, p<.001 ; \mathrm{b}-1$ and $3, p<.05$.

Strategies: S.1. Aggressive and destructive behaviours, S.2. Substitute activities, S.3. Avoidance and escape, S.4. Soothing or releasing emotions, S.5. Conscious coping with problem, S.6. Controlling one's emotions and behaviour.

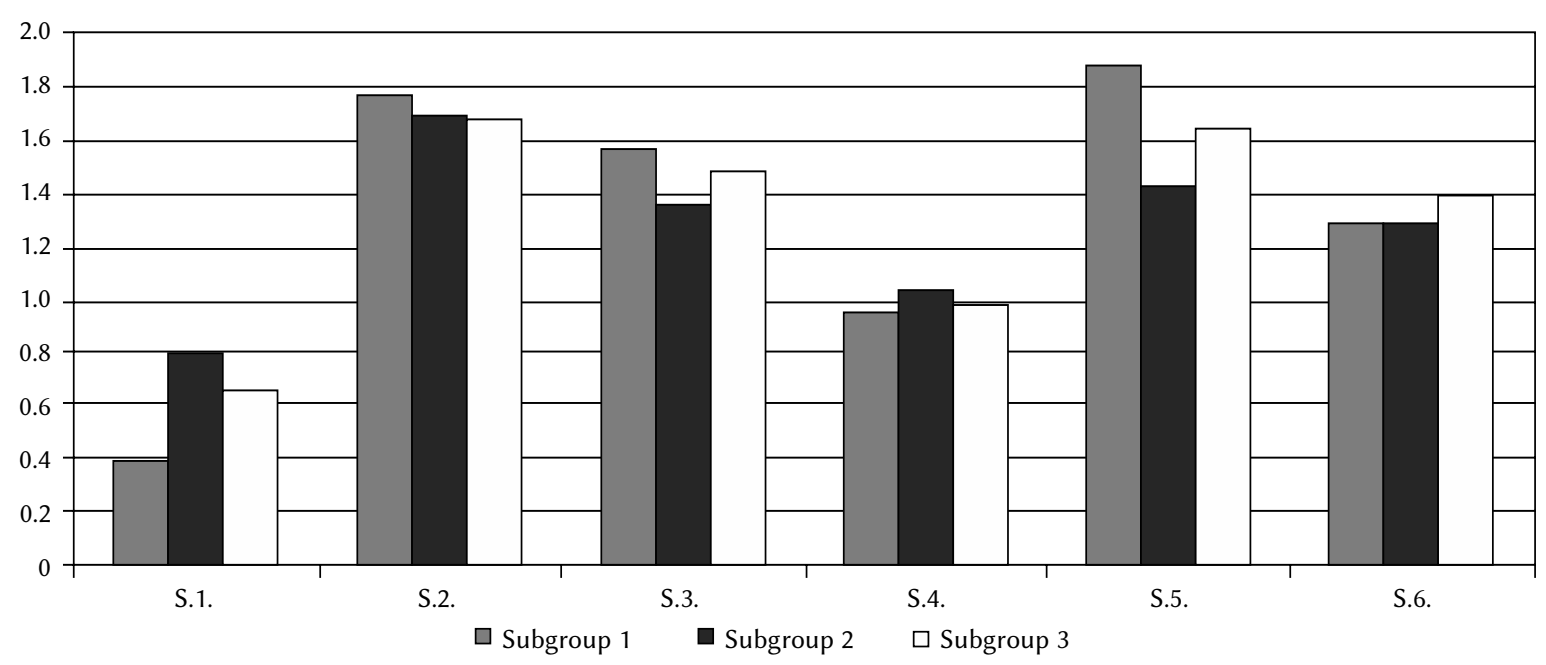

Strategies: S.1. Aggressive motor behaviours, S.2. Distracting activities, S.3. Avoidance and escape, S.4. Soothing or abreacting emotions, S.5. Conscious addressing of the problem, S.6. Controlling one's emotions and behaviour.

Figure 5. Frequency of use of coping strategies in the three subgroups of youth.

destructive activities - that is outward aggression or destructive behaviours.

In order to answer the research question about the levels of subjective quality of life of youth and verify the hypothesis about significantly higher levels of quality of life in resilient youth, a comparative analysis of quality of life scores was conducted (YQOL), and the results are presented in Table 5 and Figure 6.

Statistically significant differences between the subgroups were observed both in terms of the overall score (the lowest level of subjective quality of life characterised subjects from the risk subgroup) and in all four of the domains. Participants from the resilient subgroup were found to have satisfactory levels of subjective quality of life, despite experiencing illness and its associated problems.

The most characteristic result was observed in the general satisfaction with life domain. We found that that youth who scored high in that regard, de- spite their difficult situation, have the ability to see the value of life, to enjoy it and to feel that it has a purpose and meaning. Ill teenagers from the resilient subgroup possess the ability to see opportunities to engage in and to undertake activities within their community, opportunities to study despite the illness and have a positive outlook on their future, despite the limitations imposed by their illness and the related treatment. One can say that this subgroup is somewhat optimistic. The lowest scores of subjects from the risk subgroup are in the sense of self, social relations, and general quality of life. This means that these individuals assess their physical and mental health the lowest, they do not believe in themselves enough to overcome difficulties, and they are not satisfied with their relations with family, peers, and friends. They lack support from adults, a sense of freedom in action and the skills to engage in communal activities with others. In such circumstances, 
Table 5

Subjective quality of life - results (M and SD) on the YQOL scale for the 3 subgroups of youth; results of ANOVA

\begin{tabular}{lcccccccc}
\hline \multicolumn{1}{c}{ Quality of life } & \multicolumn{3}{c}{ Subgroup $1(n=54)$} & Subgroup $2(n=43)$ & Subgroup $3(n=65)$ & \multicolumn{2}{c}{$\begin{array}{c}\text { Significance } \\
\text { of differences }\end{array}$} \\
\cline { 2 - 10 } & $M$ & $S D$ & $M$ & $S D$ & $M$ & $S D$ & $F(2,152)$ & $p$ \\
\hline 1. Sense of self & 74.92 & 13.77 & 57.10 & 16.70 & 67.30 & 12.85 & $18.68^{\mathrm{a}, \mathrm{b}, \mathrm{c}}<.001$ \\
2. Social relationships & 83.64 & 22.77 & 58.36 & 19.34 & 72.57 & 13.54 & $29.26^{\mathrm{a}, \mathrm{b}, \mathrm{c}}<.001$ \\
3. Environment & 83.96 & 11.60 & 67.56 & 20.20 & 77.88 & 12.16 & $15.34^{\mathrm{a}, \mathrm{b}}$ & $<.001$ \\
4. General QoL & 83.64 & 22.77 & 59.53 & 27.71 & 78.77 & 20.51 & $13.97^{\mathrm{a}, \mathrm{b}}$ & $<.001$ \\
\multicolumn{1}{c}{ QoL-Total } & 80.77 & 12.04 & 60.64 & 18.75 & 74.16 & 12.69 & $24.06^{\mathrm{a}, \mathrm{b}, \mathrm{c}}<.001$ \\
\hline
\end{tabular}

Note. Differences: a - between 1 and 2 ; b - between 2 and 3, $p<.001 ; \mathrm{c}-$ between 1 and $3, p<.01$.

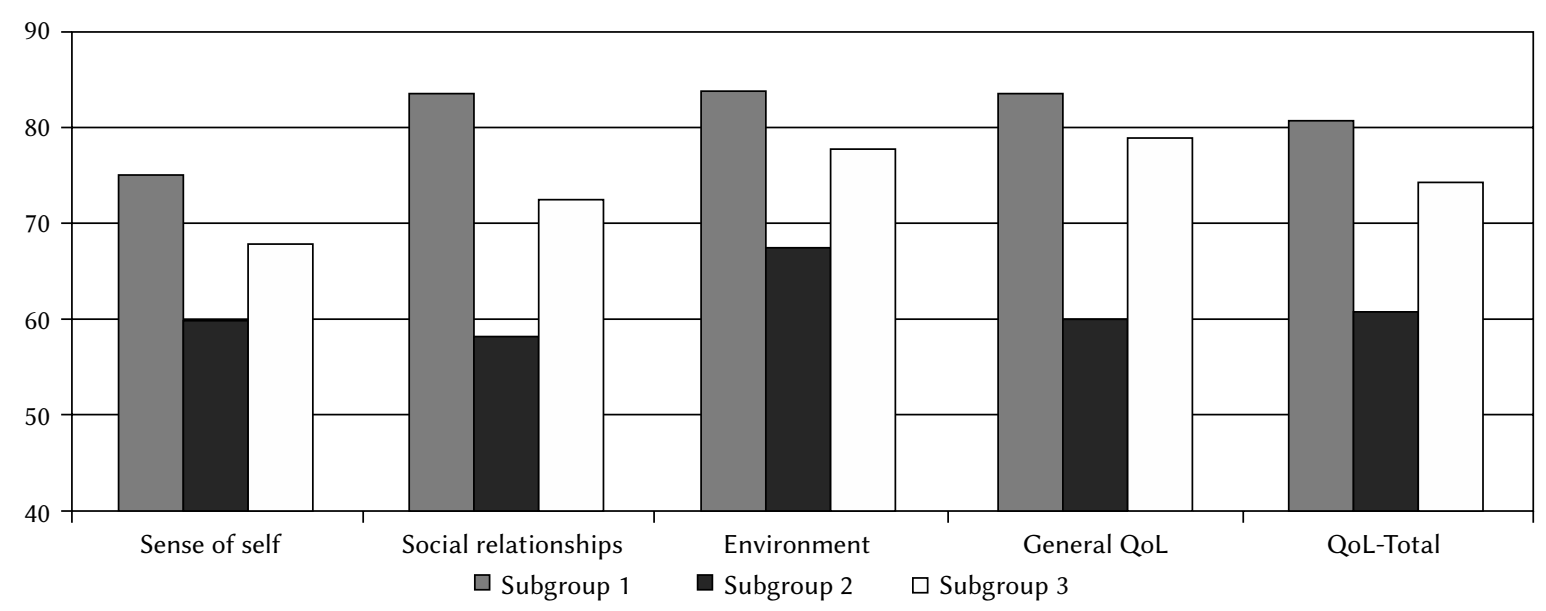

Figure 6. Level of subjective quality of life (overall score and scores for particular domains) for the three subgroups of youth.

they may have a sense of being different, or even a sense of social alienation.

The use of the Polish adaptation of the Children's Depression Inventory (CDI) by Kovacs allowed for assessment of the intensity of depressive reactions of the investigated youth, and for verifying the hypothesis about low levels of depressive symptoms among resilient youth. Results indicate significantly higher levels of depressive reactions among teenagers from the risk subgroup (Table 6, Figure 7).

Teenagers from the resilient subgroup were characterised by the lowest levels of depressive reactions, while the risk group had the highest. The presence of depressive symptoms in this subgroup may not mean that they suffer from clinical depression, but it definitely indicates a risk of its occurrence if there is a lack of effective psychological intervention.

\section{DISCUSSION AND CONCLUSIONS}

The goal of this article is to present the problem of resilience and the results of studying chronically ill youths and their mental resilience and positive adaptation. This is why the discussion will extend outside of the study results in order to analyse the phenomenon of resilience in a broader context. The following variables were chosen as resilience criteria: social skills, sense of self-efficacy, sense of self and sense of social support. The following variables were chosen as indices of positive adaptation: coping, high levels of subjective quality of life, and low levels of depressive symptoms.

Chronic illness is a type of prolonged stress situation, which is why it is a risk factor for mental health issues and emotional issues, occurrence of maladaptive reactions, lack of adaptation, decrease in wellbeing and low quality of life. Personal and external resources are important in the process of dealing with illness of a chronic character. They serve as protective factors facilitating the adaptation process, which can occur despite a stress situation such as illness. Such resources (protective factors determining adaptation) include the ability to cope, social skills/ competences, sense of self efficacy and perceived social support. Three subgroups were identified among the participants based on these variables. It is possible to identify individuals characterised by different levels of internal and external resources among the teenagers struggling with chronic illnesses. Gener-
Resilience and quality of life in youth 
Table 6

Levels of depressive reactions among subgroups of youths - results ( $M$ and $S D)$ for the CDI inventory; results of ANOVA

\begin{tabular}{|c|c|c|c|c|c|c|c|c|}
\hline \multirow[t]{2}{*}{ Depression } & \multicolumn{2}{|c|}{$\begin{array}{l}\text { Subgroup } 1 \\
\quad(n=54)\end{array}$} & \multicolumn{2}{|c|}{$\begin{array}{l}\text { Subgroup } 2 \\
\quad(n=43)\end{array}$} & \multicolumn{2}{|c|}{$\begin{array}{l}\text { Subgroup } 3 \\
\quad(n=65)\end{array}$} & \multicolumn{2}{|c|}{$\begin{array}{l}\text { Significance of } \\
\text { differences }\end{array}$} \\
\hline & $M$ & $S D$ & $M$ & $S D$ & $M$ & $S D$ & $F(2,155)$ & $p$ \\
\hline CDI & 47.56 & 8.79 & 61.52 & 12.94 & 51.67 & 10.14 & $21.08^{a, b}$ & $<.001$ \\
\hline
\end{tabular}

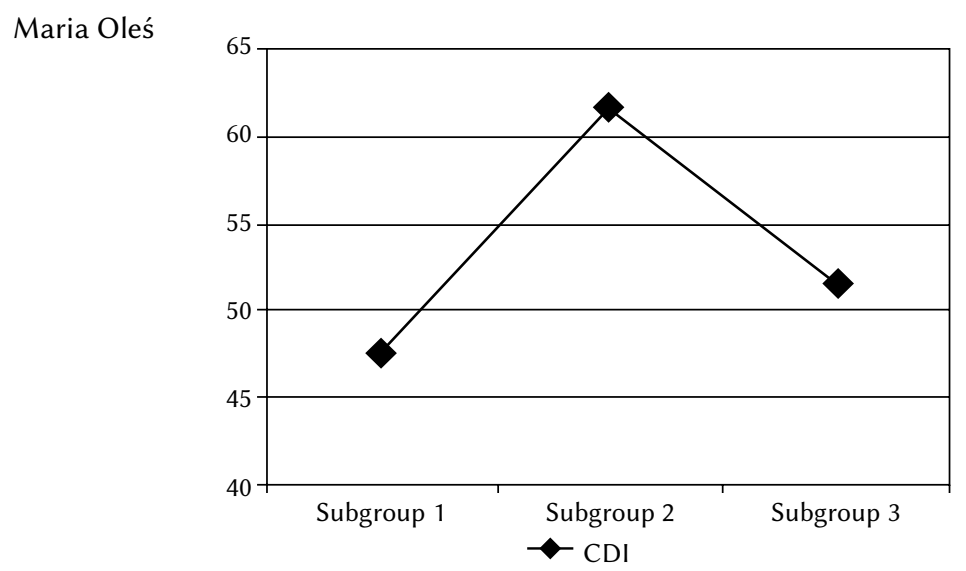

Figure 7. Levels of depressive reactions in the subgroups of youths.

ally, three subgroups were identified in the group of hospitalised chronically ill teenagers, and these subgroups can be described as:

1) well adapted youths, who are characterised by adequately developed social skills and competences, sense of self efficacy, and social support. These individuals use adaptive strategies of coping, and they are characterised by the highest levels of subjective quality of life and the lowest levels of depressive reactions when compared to the two remaining subgroups. These are people who, despite struggling with illness, are characterised by the ability to positively adapt and be resilient;

2) maladapted youths, who are characterised by decreased levels of social skills, a low sense of self-efficacy, and low perceived social support. Such individuals use maladaptive strategies of coping, have significantly lower subjective quality of life (both in the general sense and within its particular domains), and high levels of depressive reactions. They are a risk group, for whom an illness is a serious interference and threat, especially in the context of weak internal and external resources. There is a serious threat that if they do not receive support and help from other sources, their own internal and external resources will not be sufficient for them to successfully cope with the illness and develop normally. The risk of maladaptation, emotional difficulties and depressive reactions is high. This suggests the need to monitor such indi- viduals, including detailed screening for emotional disorders, and to make psychological help readily available to them;

3) individuals with average adaptation levels, characterised by average levels of social skills and competences, sense of self-efficacy, and perceived social support. This subgroup of youth is characterised by an average ability to cope with stress and average levels of depressive reactions. Such individuals score average on subjective quality of life. These are people of average levels of resilience, averagely adapted to their situation.

Analogical subgroups of high, moderate and low resilience were identified by Yi, Vitaliano, Smith, Yi and Weinger (2008) in a group of youths with diabetes. A similar method was used by researchers investigating university students, among whom they identified those who were resilient, characterised by a stable level of satisfaction and differing from the remaining students in terms of personality features, perceptions of stress and coping strategies. The studies suggest that it is not the features of one's personality, but rather the perceptions of stress and ability to cope that are more important for satisfaction with life (Kjeldstadli et al., 2006). Referring to the cited research, one could say that the possessed internal and external resources are the factors which differentiate the subjects, independently of belonging to the common category of chronically ill.

Based on the assessment of levels of the selected psychosocial variables as criterion variables of resilience, a subgroup of resilient youth - individuals with average levels of resilience - and a subgroup of increased susceptibility and risk were selected. The results of the current study allowed us to verify hypotheses about differences in terms of adaptation in accordance with differences in resilience levels, indicators of which were social skills, sense of self-efficacy and perceived social support.

The hereby identified subgroups of youth differ significantly in terms of the listed adaptation variables - coping and subjective quality of life - but also in terms of depressive symptoms, which indicate lack of adaptation. The smallest number of differences was observed in terms of the coping strategies (substitute activities, avoidance and escape, soothing or releasing emotions, controlling one's emotions and 
behaviours). This suggests that, independently of the resilience levels, in difficult and stressful situations youths use coping strategies of avoidance-escape, substitute activities, soothing or releasing emotions, as well as control over emotions and behaviours equally often. Significant differences were observed with regards to two coping strategies: aggressive activity (highest in the risk subgroup) and conscious coping with the problem (used most frequently by resilient youth).

Resilient youth were characterised by significantly higher levels of subjective quality of life in comparison with the other subgroups, in terms of the overall score, general satisfaction with life, sense of self, social relations and satisfaction with opportunities within one's environment. Such a result is not surprising - the relationship between resilience and quality of life was also suggested by research by Ogińska-Bulik (2010b).

Increased levels of depressive reactions were exhibited by youths in the risk subgroup. There is an additional threat that if, in a situation of illness, no other supportive factors (that were not measured in this study) are at work, people from this subgroup may be susceptible to adverse effects and negative consequences of stress associated with illness. Negative effects of an illness may have unfavourable effects on the further development and future of the affected youth. It is important to note that the period of adolescence is a time of transitioning from childhood into adulthood, and, accordingly, it is a difficult time, full of challenges, new tasks but also new threats (Oleszkowicz, 1995). The co-occurrence of chronic illness alongside the normal developmental processes causes an additional strain for the natural processes of development and coping with the typical tasks of that period. Fear about the future and uncertainty about the efficacy of received treatment may intensify if a young individual does not possess strong backup in the form of personal and external resources. Limitations related to an illness, negative experiences caused by the condition, medical procedures and hospitalisations, barriers in the social domain and the lack of a sense of belongingness (which is particularly important in this developmental period) may cause emotional instability, emotional disorders and impairments in the process of identity formation (Szewczyk, 2007).

The current study did not measure resilience directly. Many studies suggest that it is possible to make inferences about mental resilience by measuring related variables. For instance, Gomez et al. (2013) point to correlates of resilience such as positive affect, gratitude or subjective happiness. Research also suggests that higher levels of resilience correlate with higher self-esteem and hope among chronically ill children (Grey, Boland, Yu, Sullivan-Bolyai, \& Tamborlane, 1998). Schiner and Masten (2012) believe that resil- ience can be defined in terms of competences that are important for adaptation, such as academic achievements, adherence to rules or social competences (cf. Masten \& Obradović, 2006). Psychosocial resources such as self-esteem, optimism, sense of self-efficacy and sense of self-agency are widely used in research concerned with resilience. Therefore they can be treated as resources of resilience, which may serve as protection in the face of stress associated with illness. In a study by Yi et al. (2008) resilience was defined through results of measurements of self-esteem, sense of self-efficacy, sense of self-agency and optimism. Another indicator of resilience is competence (Garmezy, Masten, \& Tellegen, 1984). Social competences were associated with higher levels of emotional wellbeing, abilities to cope with stress and better metabolic control among youth with type 1 diabetes. The goal of the diabetes study was to reveal the most adaptive strategies of coping and assessment of how the use of specific strategies of coping influences resilience. The use of adaptive strategies of coping was associated with higher levels of competences, higher quality of life and better metabolic control. The use of unfavourable coping strategies was associated with lower levels of competences. The study indicates that adaptive coping is associated with resilience (Jaser \& White, 2012). Positive indicators of satisfactory adaptation to type 1 diabetes such as quality of life and metabolic control may be treated as indicators of resilience (Luthar, Cicchetti, \& Brown, 2000; Masten, 2007).

The individual and social resources that a teenager possesses are important for their levels of resilience and coping strategies. Internal resources include optimism, control, sense of self-efficacy, and active coping (Lee et al., 2012). Many studies suggest that social skills and competences have protective properties in situations of stress (Masten, 2007). Research indicates that children who are resilient to stress are characterised by higher levels of empathy, the ability to successfully resolve social problems and the use of adaptive strategies of coping (Luthar \& Zigler, 1991; Parker, Cowen, Work, \& Wyman, 1990). Previous research suggests that features of resilient children include good intellectual functioning, sociability, sense of self-efficacy, self-confidence and high self-esteem, internal locus of control and social competences. Commonly identified attributes of a resilient child include responsibility, elasticity, empathy and care, social skills, sense of humour and other pro-social behaviours (Benard, 1991), social competences, ability to solve problems, autonomy, sense of purpose and meaning in life and the future (Benard, 2004). For children who experience threatening and difficult situations, efficient coping is associated with features such as reflexivity, sense of self-efficacy, easy temperament, self-esteem and high levels of cognitive skills (Garmezy, 1991). These abilities allow a child to react to challenges in an adaptive manner and use
Resilience and quality of life in youth 
the resources in their social environment. This allows for healthy and normal development in the face of adversity (Masten, 1992). External resources include social support. Support from one's family is an important resource for the quality of life, coping, and resilience of a child (Armstrong, Birnie-Lefcovitch, Ungar, \& Friesen, 2005). Social support has a positive effect on resilience (Amer, 1999). Among protective factors, Benard (1991) lists care and support from the family, high expectations from the family and social environment (e.g. school) with simultaneous support and help, and the opportunity to actively participate and engage in activities at school or in the broader community. Some authors put particular emphasis on two potential processes of resilience: coping and social competences. Access to these psychosocial resources nullifies or moderates the destructive influence of the stressful situation. These processes may be particularly important in protection against the negative effects of stress and risk of pathology associated with parents' depression (Reeslund, 2010). Some interesting results from research on African children were presented by Camfield (2012). These results suggest that social resources and social competences play an important role for their resilience and wellbeing. Despite the poverty of the society they live in, they are happy and satisfied with their lives. This shows the huge importance of resilience as an ability to bounce back from adverse experiences. The social competences that allowed a child to build a social support network played a particular role. In Europe and America resilience tends to be researched in the context of individual competences such as self-confidence (Camfield, 2012).

Studies by many researchers also assumed the existence of intermediate variables - individual and environmental protective factors - that play a crucial role in the processes taking place between risk factors (such as violence and illness) and psychosocial development and adaptation. These variables create a system which is described in the model of adaptation to chronic illness based on the example of diabetes (Childhood Adaptation Model to Chronic Illness: Diabetes Mellitus) (Whittemore, Jaser, Guo, \& Grey, 2010). Another example of a model which includes risk factors, protective factors, resilience and quality of life is the model developed based on research on youths affected with cancer - the Adolescent Resilience Model (ARM) (Haase, 2004). In the Child Resilience Model by Vinson (2002), in explaining the consequences of illness among children suffering from asthma the following variables are identified as important: family environment (warmth and cohesion), specific features of the child (sense of coherence, competences and skills, positive self-esteem), situation assessment, coping and positive adaptation (quality of life dependent on health, illness parameters and its effects). The susceptibility of a child to negative effects and risks associated with illness can be nullified by protective factors (internal and external). If these factors are at work, the child may develop resilience and a state of wellbeing. Specific patterns of coping and problem-solving skills allow one to influence one's environment as well as allowing one to adjust one's reactions to a situation that cannot be changed (chronic illness) and in doing so they foster the child's resilience and quality of life. Research by Ogińska-Bulik and Kobylarczyk (2015) suggests that children from orphanages with higher subjective quality of life are characterised by higher levels of resilience and social support. In research on teenagers with cancer by $\mathrm{Wu}$ et al. (2015) resilience is an intermediate variable between the symptoms of distress caused by the illness and quality of life. Most of the studied patients were characterised by average or high levels of resilience. A positive correlation was found between resilience and quality of life together with levels of social support. Increasing resilience (e.g. by increasing social support, working on better cognitive strategies, acceptance of the illness and making efforts to get back to health) may lead to higher quality of life and lower levels of psychological distress. Resilience as a process and as an effect is a goal of treatment, and may broaden potential and increase quality of life (Haase et al., 1999). Positive results of struggling with adversities, lack of psychopathological symptoms, satisfaction with life and quality of life may also indicate resilience (Alriksson-Schmidt et al., 2006).

In conclusion, the research results can be summed up in the following points:

1. Among youths who deal with chronic illness there are individuals who are resilient, exhibit good adaptation despite the illness-associated stress and adversities, individuals of moderate, average levels of resilience, and individuals who do not cope well, characterised by low wellbeing and a risk of emotional disorders.

2. Assuming that high social competences, sense of self-efficacy and perceived social support are indices of resilience, youths of different levels of these features differ in terms of adaptation.

3. Youths characterised by high levels of resilience are different from other subgroups in terms of the used coping strategies, subjective quality of life and the occurrence of depressive symptoms.

In a risk situation such as a chronic illness, it is extremely important to detect individuals whose levels of resources and resilience are insufficient to cope, whose adaptation process proceeds in a way that is not optimal for their development, who report low perceived quality of life, show symptoms of depression, and who use maladaptive strategies for coping - all of which pose a risk of further disorders. Hence, it is important to work towards building personal and external resources, shaping coping skills for the nor- 
mal course of development and adaptation processes. Therefore there is a need for a multidimensional, dynamic approach, which includes not only the assessment of risk factors and protective factors, but also assessment of the processes that take place in between stress and adversities, and their negative consequences for an individual (Rutter, 2013). Forms of action aimed at strengthening the resources and resilience of youth are recommended as parallel to research. Some examples of such prevention frameworks are the Positive Youth Development (PYD) concept (Lerner, Almerigi, Theokas, \& Lerner, 2005), Developmental Assets Framework (DAF) (Leffert et al., 1998), which focuses on the assets of an individual, and the Youth Resilience Framework (Rew \& Horner, 2003).

One of the limitations of the current research project could be the fact that resilience was inferred on the basis of several parameters, which might be described as attributes of resilience - the variable was not measured directly, using a reliable and valid measurement tool. Hence, it would be beneficial to verify the results, using a method with an established psychometric value, designed for measuring resilience e.g. Perceived Stress Scale-18 (PSS-18, Ogińska-Bulik, 2010b) or the Connor-Davidson Resilience Scale (CDRISC, Connor \& Davidson, 2003). The levels of stress experienced in association with the illness were also not measured, and the non-categorical approach did not account for the specifics of a given illness or its severity. The current project also did not investigate other variables that may serve a protective function in dealing with illness-associated stress. It may be valuable to include a cognitive assessment of illness and other internal and external resources in future studies on resilience and quality of life of the chronically ill.

\section{REFERENCES}

Alriksson-Schmidt, A. I., Wallander, J., \& Biasini, F. (2006). Quality of Life and Resilience in Adolescents with a Mobility Disability. Journal of Pediatric Psychology, 32, 370-379.

Amer, K. S. (1999). Children's adaptation to insulin dependent diabetes mellitus: a critical review of the literature. Paediatric Nursing, 25, 627-631.

Armstrong, M., Birnie-Lefcovitch, S., Ungar, M., \& Friesen, B. (2005). Pathways between social support, family well being, quality of parenting, and child resilience: What we know. Journal of Child and Family Studies, 14, 269-281.

Bandura, A. (1999). Self-efficacy: Toward a unifying theory of behavioral change. In: R. F. Baumeister (ed.), The Self in Social Psychology (pp. 285-297). Ann Arbor: Psychology Press.

Benard, B. (1991). Fostering Resiliency in Kids: Protective Factors in Family, School, and Community. Washington: Department of Education.
Benard, B. (2004). Resiliency: What we have learned. San Francisco: WestEd.

Bolig, R., \& Weddle, K. D. (1988). Resiliency and Hospitalization of Children. Children's Health Care: Journal of the Association for the Care of Children's Health, 16, 255-260.

Borucka, A. (2011). Koncepcja resilience. Podstawowe założenia i nurty badań [The concept of resilience. Main principles and research trends]. In: W. Junik (ed.), Teoria - badania - praktyka. Resilience [Resilience - theory and research] (pp. 11-28). Warszawa: Wydawnictwo Edukacyjne PARPAMEDIA.

Borucka, A., \& Ostaszewski, K. (2008). Koncepcja resilience. Kluczowe pojęcia i wybrane zagadnienia. [The concept of resilience. Key terms and selected problems]. Medycyna Wieku Rozwojowego, 12, 587-597.

Borucka, A., \& Ostaszewski, K. (2012). Czynniki i procesy resilience wśród dzieci krzywdzonych [Factors and resilience processes among maltreted children]. Dziecko Krzywdzone, 40, 7-22.

Brown, R. T., Daly, B. P., \& Rickel, A. U. (2007). Chronic Illness in Children and Adolescents. Advances in Psychotherapy. Evidence-Based Practice. Cambridge, MA: Hogfree \& Huber Publishers.

Camfield, L. (2012). Resilience and well-being among urban Ethiopian children: what role do social resources and competencies play? Social Indicators Research, 107, 393-410.

Canty-Mitchell, J., \& Zimet, G. D. (2000). Psychometric Properties of the Multidimensional Scale of Perceived Social Support in Urban African-American Adolescents. American Journal of Community Psychology, 28, 391-401.

Cierpiałkowska, L. (2007). Dzieci alkoholików w perspektywie rozwojowego modelu podatności i odporności na zaburzenia psychiczne [Children of alcoholics in the context of the developmental model of vulnerability and resilience to mental disorders]. Czasopismo Psychologiczne, 13, 7-18.

Catalano, R. F., Berglund, M. L., Ryan, J. A. M., Lonczak, H. S., \& Hawkins, J. D. (2004). Positive youth development in the United States: research findings on evaluations of positive youth development programs. Annals of the American Academy of Political and Social Science, 591, 98-124.

Connor, K. M., \& Davidson, J. R. (2003). Development of a new resilience scale: the Connor-Davidson Resilience Scale (CD-RISC). Depression and Anxiety, 18, 76-82.

Drotar, D. (1998). Measuring health-related quality of life in children and adolescents. Implications for research and practice. Mahwah, NJ: Lawrence Erlbaum Associates, Publishers.

Garmezy, N. (1991). Resilience in children's adaptation to negative life events and stressed environments. Pediatrics, 20, 459-466.
Resilience and quality of life in youth 
Garmezy, N., Masten, A. S., \& Tellegen, A. (1984). The study of stress and competence in children: a building block for developmental psychopathology. Child Development, 55, 97-111.

Gomez, M., Vincent, A., \& Toussaint, L. L. (2013). Correlates of resilience in adolescents and adults. International Journal of Clinical Psychiatry and Mental Health, 1, 18-24.

Gresham, F. M., \& Elliott, S. N. (1990). Social Skills Rating System manual. Circle Pines, MN: American Guidance Service.

Grey, M., Boland, E. A., Yu, C., Sullivan-Bolyai, S., \& Tamborlane, W. V. (1998). Personal and family factors associated with quality of life in adolescents with diabetes. Diabetes Care, 21, 909-914.

Haase, J. E. (2004). The Adolescent resilience model as a guide to intervention. Journal of Pediatric Oncology Nursing, 21, 289-299.

Haase, J. H. E., Heiney, S. P., Ruccione, K. S., \& Stutzer, C. (1999). Research triangulation to derive meaning-based quality-of-life theory: adolescent resilience model and instrument development. International Journal of Cancer: Supplement, 12, 125-131.

Heszen, I., \& Sęk, H. (2007). Psychologia zdrowia [Health Psychology]. Warszawa: Wydawnictwo PWN.

Jaser, S. S., \& White, L. E. (2011). Coping and resilience in adolescents with type 1 diabetes. Child Care Health Development, 37, 335-342.

Kjeldstadli, K., Tyssen, R., Finset, A., Hem, E., Gude, T., Gronvold, N. T., Ekeberg, O., \& Vaglum, P. (2006). Life satisfaction and resilience in medical school - a six-year longitudinal, nationwide and comparative study. BMC-Medical Education, 6, 48.

Kovacs, M. (1980/81). Rating Scales to Assess Depression in School Aged Children. Acta Paedopsychiatrica, 46, 305-315.

Lawford, J., \& Eiser, C. (2001). Exploring links between the concepts of quality of life and resilience. Pediatric Rehabilitation, 4, 209-216.

Lee, T. Y., Cheung, C. K., \& Kwong, W. M. (2012). Resilience as Positive Youth Development Construct: A Conceptual Review. The Scientific World Journal. DOI: $10.1100 / 2012 / 390450$.

Leffert, N., Benson, P. L., Scales, P. C., Sharma, A. R., Drake, D. R., \& Blyth, D. A. (1998). Developmental assets: measurement and prediction of risk behaviors among adolescents. Applied Developmental Science, 2, 209-230.

Lerner, R. M., Almerigi, J. B., Theokas, C., \& Lerner, J.V. (2005). Positive youth development. a view of the issues. Journal of Early Adolescence, 25, 10-16.

Luthar, S. S. (1991). Vulnerability and resilience: a study of high-risk adolescents. Child Development, 62, 600-616.

Luthar, S. S. (ed.) (2003). Resilience and vulnerability: Adaptation in the context of childhood adversities. Cambridge: Cambridge University Press.
Luthar, S. S., Cicchetti, D., \& Brown, B. (2000). The construct of resilience: a critical evaluation and guidelines for future work. Child Development, 71, 543-562.

Luthar, S. S., Sawyer, J. A., \& Brown, P. J. (2006). Conceptual issues in studies of resilience. past, present, and future research. Annals New York Academy of Sciences, 1094, 105-115.

Luthar, S. S., \& Zigler, E. (1991). Vulnerability and competence: a review of research on resilience in childhood. American Journal of Orthopsychiatry, 61, 6-22.

Masten, A. S. (1992). Resilience in development: Implications of the study of successful adaptation for developmental psychopathology. In: A. Sameroff (ed.), Developmental Psychopathology (pp. 261-294). New York: Wiley.

Masten, A. S. (2001). Ordinary magic: Resilience processes in development. American Psychologist, 56, 227-238.

Masten, A. S. (2007). Resilience in developing systems: progress and promise as the fourth wave rises. Development and Psychopathology, 19, 921-930.

Masten, A. S., Best, K., \& Garmezy, N. (1990). Resilience and development: contributions from the study of children who overcome adversity. Development and Psychopathology, 2, 425-444.

Masten, A., \& Gewirtz, A. H. (2006). Resilience in development: The importance of early childhood. In: R. E. Tremblay, R. G. Barr, \& R. De V. Peters (eds.), Encyclopedia on Early Childhood Development (pp. 1-6) [online]. Montreal, Quebec: Centre of Excellence for Early Childhood Development. Available at: http:/www.child-encyclopedia.com/ documents/Masten-GewirtzANGxp.pdf.

Masten, A., \& Obradović, J. (2006). Competence and resilience in development. Annals of the New York Academy of Sciences, 1094, 13-27.

Masten, A., \& Reed, M.-G. J. (2005). Resilience in development. In: C. R. Snyder, \& S. J. Lopez (eds.), Handbook of Positive Psychology (pp. 74-88). New York: Oxford University Press.

Muris, P. (2002). Relationships between self-efficacy and symptoms of anxiety disorders and depression in a normal adolescent sample. Personality and Individual Differences, 32, 337-348.

Nowakowska, M. (1983). Psychologiczne aspekty chorób przewlekłych, trwałego upośledzenia zdrowia oraz chorób nieuleczalnych i zagrażających życiu [Psychological aspects of chronic illnesses, permanent impairment to health as well as incurable and life-threatening conditions]. In: M. Jarosz (ed.), Psychologia lekarska [Medical Psychology] (pp. 343-362). Warszawa: PZWL.

Ogińska-Bulik, N. (2010a). Pozytywne zmiany w następstwie doświadczonej traumy - zjawisko potraumatycznego rozwoju [Positive changes followingtrauma - the phenomenon of post-trau- 
matic development]. In: L. Suchocka, \& R. Sztembis (eds.), Człowiek i dzieło. Księga jubileuszowa dedykowana Księdzu Profesorowi Kazimierzowi Popielskiemu [Man and his works. The Jubilee book dedicated to Father Prof. Kazimierz Popielski] (pp. 193-203). Lublin: Wydawnictwo KUL.

Ogińska-Bulik, N. (2010b). Prężność a jakość życia młodzieży [Resilience and the quality of life in youth]. Psychologia Jakości Życia, 1, 233-247.

Ogińska-Bulik, N. (2013). Pozytywne skutki doświadczeń traumatycznych, czyli kiedy łzy zamieniaja się w perty [When tears become pearls - positive outcomes of traumatic experiences]. Warszawa: Wydawnictwo Difin.

Ogińska-Bulik, N., \& Kobylarczyk, M. (2015). Resiliency and social support as factors promoting the process of resilience in adolescents - wards of children's homes. Health Psychology Report, 3. DOI: 10.5114/hpr.2015.49045.

Oleszkowicz, A. (1995). Kryzys mtodzieńczy - istota i przebieg [The Crisis of Adolescence - its nature and course]. Wrocław: Wydawnictwo Uniwersytetu Wrocławskiego.

Oleś, M. (1995). Pomiar depresji: przegląd metod [Measuring depression: a review of methods]. Roczniki Filozoficzne, 43, 147-170.

Oleś, M. (2010). Jakość życia mtodzieży w zdrowiu $i$ w chorobie [Quality of life of youth, in health and in illness]. Lublin: Redakcja Wydawnictw KUL.

Olsson, C., Bond, L., Burns, J., Vella-Brodick, D., \& Sawyer, S. (2003). Adolescence resilience: a concept analysis. Journal of Adolescence, 26, 1-11.

Ostaszewski, K. (2005). Druga strona ryzyka [The other side of risk]. Remedium, 2, 1-3.

Parker, G. R., Cowen, E. L., Work, W. C., \& Wyman, P. A. (1990). Test correlates of stress-resilience among urban school children. Journal of Primary Prevention, 11, 19-35.

Patrick, D. L., Edwards, T. C., \& Topolski, T. D. (2002). Adolescent quality of life. Part II: initial validation of a new instrument. Journal of Adolescence, 25, 287-300.

Pilecka, W. (2002). Przewlekła choroba somatyczna w życiu i rozwoju dziecka. Problemy psychologiczne [Chronic somatic illness in the life and development of a child. Psychological problems]. Kraków: Wydawnictwo Uniwersytetu Jagiellońskiego.

Reeslund, K. L. (2010). Coping and social competence as processes of resilience in a family cognitive-behavioral preventive intervention for children of depressed parents. Dissertation. Tennessee: Graduate School of Vanderbilt University.

Rew, L. (2005). Adolescent Health. A multidisciplinary Approach to Theory, Research, and Intervention. Thousand Oaks: Sage Publications.

Rew, L., \& Horner, S. D. (2003). Youth resilience framework for reducing health-risk behaviors in adolescents. Journal of Pediatric Nursing, 18, 379-388.
Richardson, G. E. (2002). The metatheory of resilience and resiliency. Journal of Clinical Psychology, 58, 307-321.

Rutter, M. (1980). Changing youth in a changing society: Patterns of adolescent development and disorder. Cambridge, MA: Harvard University Press.

Rutter, M. (1985). Resilience in the face of adversity: protective factors and resistance to psychiatric disorder. British Journal of Psychiatry, 147, 598-611.

Rutter, M. (1987). Psychosocial resilience and protective mechanism. American Journal of Orthopsychiatry, 57, 316-331.

Rutter, M. (1990). Psychosocial resilience and protective mechanisms. In: S. Weintraub (ed.), Risk and protective factors in the development of psychopathology (pp. 181-214). Cambridge: Cambridge University Press.

Rutter, M. (1993). Resilience: Some conceptual considerations. Journal of Adolescent Health, 14, 626-631.

Rutter, M. (2013). Annual research review: resilience - clinical implications. Journal of Child Psychology and Psychiatry, 54, 474-487.

Ryan-Wenger, N. M. (1990). Development and psychometric properties of the Schoolagers' Coping Strategies Inventory. Nursing Research, 39, 344-349.

Ryan-Wenger, N. M. (1992). A taxonomy of children's Coping strategies: A step toward Theory Development. American Journal of Orthopsychiatry, 62, 256-263.

Schiner, R. L., \& Masten, A. S. (20012). Childhood personality as a harbinger of competence and resilience in adulthood. Development and Psychopathology, 24, 507-528.

Stewart, M., Reid, G., \& Mangham, C. (1997). Fostering children's resilience. Journal of Pediatric Nursing, 12, 21-31.

Szewczyk, L. (1987). Psychiczne następstwa zaburzeń somatycznych u dzieci i młodzieży [Mental consequences of somatic disorders in children and adolescents]. In: A. Papierkowski (ed.), Choroby wieku rozwojowego [Developmental conditions] (pp. 391-396). Warszawa: PZWL.

Szewczyk, L. (2007). Funkcjonowanie psychiczne dziewcząt i chłopców z zaburzeniami endokrynnymi [Psychological functioning of boys and girls with endocrine disorders]. In: A. Kulik, \& L. Szewczyk (eds.), Wybrane zagadnienia z psychologii klinicznej i osobowości. Tom IX. Psychospołeczne nastęstwa choroby somatycznej u dzieci [Selected problems of clinical and personality psychology, Vol. IX. Psychologicial consequences of somatic conditions in children] (pp. 47-54). Lublin: TN KUL.

The WHOQOL Group. (1995). The World Health Organization Quality of Life Assessment (WHOQOL): Position Paper from the World Health Organization. Social Science and Medicine, 41, 1403-1409.

Topolski, T. D., Edwards, T. C., \& Patrick, D. L. (2002). Youth Quality of Life Instruments. User's Manu-
Resilience and quality of life in youth 
al and Interpretation Guide. Washington: Seattle Quality of Life Group.

Wallander, J. L., \& Varni, J. W. (1998). Effects of pediatric chronic physical disorders on child and family adjustment. Journal of Child Psychology \& Psychiatry \& Allied Disciplines, 39, 29-46.

Werner, E. (1989). High-risk children in young adulthood: A longitudinal study from birth to 32 years. American Journal of Orthopsychiatry, 59, 72-81.

Werner, E. (2003). Vulnerability and resilience in adversity: A longitudinal perspective. Proceeding from the 2003 Children, Youth, Families At-Risk Conference (1-13).

Whittemore, R., Jaser, S., Guo, J., \& Grey M. (2010). A conceptual model of childhood adaptation to type 1 diabetes. Nursing Outlook, 58, 242-251. DOI: 10.1016/j.outlook.2010.05.001.

Wu, W.-W., Tsai, S.-Y., Liang, S.-Y., Liu, C.-Y., Jou, S.-T., \& Berry, D. L. (2015). The mediating role of resilience on quality of life and cancer symptom distress in adolescent patients with cancer. Journal of Pediatric Oncology Nursing. DOI: 10.1177/1043454214563758, jpo.sagepub.com.

Vinson, J. (2002). Children with asthma: initial development of the child resilience model. Pediatric Nursing, 28, 149-158.

Yi, J. P., Vitaliano, P. P., Smith, R. E., Yi, J. C., \& Weinger, K. (2008). The role of resilience on psychological adjustment and physical health in patients with diabetes. British Journal of Health Psychology, 13, 311-325.

Zimet, G. D., Dahlem, N.W., Zimet, S.G., \& Farley, G. K. (1988). The Multidimensional Scale of Perceived Social Support. Journal of Personality Assessment, $52,30-41$ 